\title{
Spreading the Bad News
}

We're using up our children's forest bank account and they'll be short of wood - unless we act now. That sums up the findings of a 1977 conference in Quebec City attended by leading Canadian foresters, politicians, bankers, wildlife representatives, union officials and university professors. The topic was forest renewal in Canada and the conclusions were shocking. As one delegate said: "We'd better spread the bad news." That was more than a year ago but the bad news hasn't reached the majority of Canadians.

The professional foresters' code of ethics obliges them to promote public understanding of forestry. Why, then, has a conference of such grave importance remained out of the public sight? How did the lack of reforestation in Canada reach the crisis stage without everyone becoming aware of it?

In answer to the first question, foresters can say they've tried to get attention. Across the country they've been meeting with politicians, writing letters, giving talks. But they're handicapped by inexperience in public communications and by the fact that forestry doesn't affect most people in a direct, visible way. It's not as glamorous as inflation or the oil crisis, even though it's going to have as great an impact on those problems unless Canadians get concerned about it right away.

The answer to the second question reflects both the vast size of our forest land and the fragmented jurisdiction over it. In each province there have been foresters who were aware of inadequate reforestation in their own locality. However, no single forester saw the whole picture and no one government was responsible for adding all the pieces together.

(Vancouver Prov. Midweek Report, August 1, 1979)

\section{Pour besoins d'affaires}

et protection de la famille,

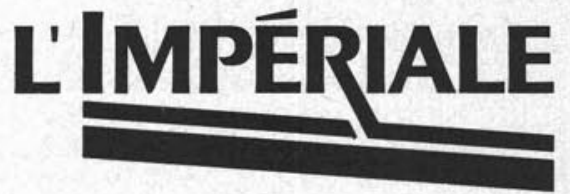

le régime flexible d'assurance-vie de l'Institut Forestier du Canada

Contrairement à la plupart des genres d'assurance collective, celui du régime de l'Institut Forestier du Canada est flexible.

II offre une réelle protection pour votre famille, si vous venez à mourir prématurément.

II peut aussi servir de garantie, à des fins d'emprunt pour affaires ou de financement pour racheter la part d'un associé.

Cette assurance est fournie par L'Impériale, Compagnie d'AssuranceVie à des taux vraiment minimes pour ce genre de protection. Sont admissibles, les membres et leur famille, ainsi que les employés à plein temps de l'Institut Forestier du Canada, qui n'ont pas atteint l'âge de 70 ans. Pour plus amples renseignements, sans obligation de votre part, écrire à Institut Forestier du Canada, B.P. 5000, Collège Macdonald, (Québec) H9X 1 C0. 